\title{
Comments on some of Britain's oldest microfossils
}

\author{
C. J. PEAT \\ Wolfson College, Oxford OX2 6UD
}

\begin{abstract}
A critical re-appraisal of some reports of British Precambrian microfossils illustrates potential pitfalls in describing Precambrian microbiotas. The Ceinwen and Llanddwyn Spilitic Formation of the Gwna Group contains convincing filamentous microfossils, but a report of acanthomorph arcitarchs has not yet been confirmed. Although the Diabaig Formation of the Torridon Group is known to be abundantly fossiliferous, a report based on S.E.M. without thin section control is rejected. Chert pebbles from the Applecross Formation of the Torridon Group do not contain convincing microfossils. They are contaminated by fungi and contain abiogenic structures which resemble cells and tissues. Reports of diagnostic Middle Riphean microfossils from the Blackbrook Formation and the Maplewell Group of the Charnian and the Buxton Rock of the Longmyndian await confirmation.
\end{abstract}

\section{INTRODUCTION}

The last 10 years have seen the development of a more critical approach to Precambrian microfossils. For once, this has been due to a reaffirmation of common-sense precepts rather than the development of new theories or sophisticated techniques. Indeed, many pseudomicrofossils have been described as a result of the inappropriate or uncritical application of high technology.

Before any microstructure can be described as a Precambrian microfossil, it must be shown to be plausibly biogenic, autochthonous, and demonstrably not an artefact. To be accepted as a cryptarch, the microstructure must also have a carbonaceous wall in a state of preservation consistent with the diagenetic and metamorphic history of the sample. Further, any microstructures recovered from macerations or similar preparations must be matched with identical or at least comparable cryptarchs in the rock. In retrospect, it is hard to see why these criteria were not applied 20 years ago. The change in attitude is illustrated by a recent review of the Archaean fossil record where, out of 43 categories of supposed microfossils, only 2 are now accepted while 6 are dubious (Schopf \& Walter, 1983). I have some doubts about all eight of these assemblages, but would certainly agree with the rejection of the remaining 35.

Late Precambrian microbiotas do not attract the same scrutiny as Archaean microfossils because the Late Precambrian fossil record is relatively well documented and one new assemblage is less likely to be of general biological significance. This is unfortunate because small mistakes can easily accumulate into gross misconceptions and there is no intrinsic reason why Proterozoic micropalaeontology should not be a rigorous discipline. I now estimate that at least half the described Proterozoic taxa are unlikely to be biogenic, of doubtful provenance, or inadequately described and in urgent need of taxonomic re-evaluation. To begin the long job of critical reappraisal and to illustrate some of the potential pitfalls, I offer the following comments on some of Britain's oldest microfossils.

\section{MONIAN}

Samples of bedded jaspers and interstitial jaspers from pillow lavas of the Ceinwen and Llanddwyn Spilitic Formation of the Gwna Group of Anglesey and Lleyn are still being studied. So far, I have not been able to confirm the presence of acanthomorph acritarchs in the original thin section or other samples from this Formation, and am therefore not sure that it is of Cambrian age (Muir et al., 1979). Convincing fossil filaments have so far only been found in samples from the jaspers of Llanddwyn (Grid. ref. SM 391634) and these probably represent filamentous microorganisms encrusted with iron (Muir et al., 1979). I have noticed that, although solitary filaments occur in the chert matrix, most filaments are found in clumps in ghosts of twinned carbonate rhombohedra now altered to chert. These and other jaspers also contain a variety of microstructures which resemble microfossils, but which grade into recrystallised fabrics and probably have an abiogenic origin.

\section{TORRIDONIAN}

The Stoer Group and the lowermost Torridon Group of northwest Scotland are abundantly fossiliferous (Downie in Stewart, 1975; Diver, 1980; Diver in Peat \& Diver, 1982). The joint attractions of knowing that the sediment was fossiliferous and using new technology and a new technique lured me into the error of describing 
microfossils without thin section control. I reported rounded microfossils and filaments from macerates of a sample from the Diabaig Formation of the Torridon Group (NG 799605; Peat \& Lloyd, 1974). The surfaces of the microstructures described as microfossils do not have the same texture as genuine cryptarchs from the same sample, nor have convincing microfossils of the same size and shape been found in thin section (my unpublished work; W. L. Diver, pers. comm.). I now interpret these microstructures as artefacts of preparation, possibly corroded minerals or precipitated silicates.

\section{PRE-TORRIDONIAN}

Britain's oldest fossils were discovered in two chert pebbles collected from the Torridonian of northwest Scotland (Muir \& Sutton, 1970). The two pebbles (S19201 and S19202 from NC194601 and NC260570 respectively, Williams, 1966a) were collected from the Applecross Formation of the Torridon Group (Stewart, 1975) as part of a general study of Torridonian sedimentation (Williams, 1966b; 1968; 1969a, b). Fossils were only found in two out of 4427 pebbles surveyed. Up to half of the pebbles examined were of exotic origin and many of them could be matched with Ketilidian rocks now exposed in East Greenland (Williams, 1969b). The chert pebbles may have a similar source, but could have come from a much younger deposit. Since the unconformity between the Torridon Group and the underlying Stoer Group represents a time gap of the order of $200 \mathrm{Ma}$ (Barber et al., 1978, p. 12), it is possible that the microfossils in the pebbles are actually younger than those from the Stoer Group.

The original thin sections are the only preparations to have survived for study (Slide numbers S19201B1, S19202B1; Geological Archive, Sedimentology Research Laboratory, Reading University; see Williams, 1969 b, p. 623 , figs. $8 F, G$ ). My new observations on them are as follows.
Several fine cracks with pale brown halos (? iron stain) cut across section S19201B1 (Pl. 1, fig. 1; pl. 2, fig. 6a). Most of the cracks contain long aseptate unbranched filaments $2-4 \mu \mathrm{m}$ in diameter which are undoubtedly fungal hyphae (Pl. 1, fig. 2). Kinks in the tubular filaments resemble septa. The filaments are contorted where the cracks are narrow or stepped, and clearly follow the cracks rather than dissolving or boring their way into the rock. The hyphae are not brightly birefringent, but are almost certainly recent contaminants, discounting the intriguing possibility that they penetrated the pebble in Torridonian times.

Parts of many of the relict ooliths in section S1 9201B1 are orange-brown in transmitted light and therefore look as if they contain carbonaceous material (PI. 1, figs. $4,6,8)$. In some places, this brown material resembles aggregations of cells. The cellular textures occur in the middle of some ooliths but are most common around the rims. They are always associated with more coarsely crystalline chert (Pl. 1 , figs. $3,5,7)$. On close examination, the brown colour can be attributed to numerous brown crystalline granules less than $1 \mu \mathrm{m}$ across which are most likely iron minerals and are definitely not specks of carbon. The cells of the cellular textures have ill-defined walls made up of these granules, and clear angular centres (Pl. 2, figs. 1-5). The densest and most convincing walls are found in the most angular cells (Pl. 2, fig. 5) which, in turn, occur in the more coarsely crystalline chert (P1. 1, figs. 7,8 ). Cells with more rounded outlines invariably have less well-defined walls (PI. 2, fig. 1), and are found in finer grained chert. From these observations I infer that the cells are abiotic, and were produced by the growth of crystals in a matrix rich in finely granular minerals.

Section S19202B1 shows only relict ooliths in contrast to the variety of clasts in S19201B1. The chert is also more uniform and not so finely crystalline. The ooliths have dark cores and rims of haematitic material, with some cellular textures. The cells are angular with dense walls and resemble those shown in Pl. 2, fig. 5 .

\section{Explanation of Plate 1}

Section S19201B1

Scale bar represents $100 \mu \mathrm{m}$ in figs. $1,3-8$ and $10 \mu \mathrm{m}$ in fig. 2. Stage co-ordinates in $\mathrm{mm}$ with S-label to left: figs. 1,2, 110.3-06.2; figs. 3, 4, 111.1-03.9; figs. 5, 6, 115.6-14.1; figs. 7, 8, 101.5-15.6. Figs. 1, 2, 4, 6, 8 in PPL (plane polarised light); figs. 3, 5, 7 in XPL (cross polarised light).

Fig. 1. Crack running through section.

Fig. 2. Detail of fig. 1 showing fungal hypha.

Figs. 3-8. Relict oolith textures. Fig. 4 shows cellular textures occurring in the centres of ooliths but these are more common in the rims (figs. 6,8). These textures are always associated with more coarsely crystalline or recrystallised chert (figs. 3, 5, 7). Details of oolith rims of fig. 6 are shown in P1. 2, figs. 1, 3 and of fig. 8 in Pl. 2, fig. 5. 

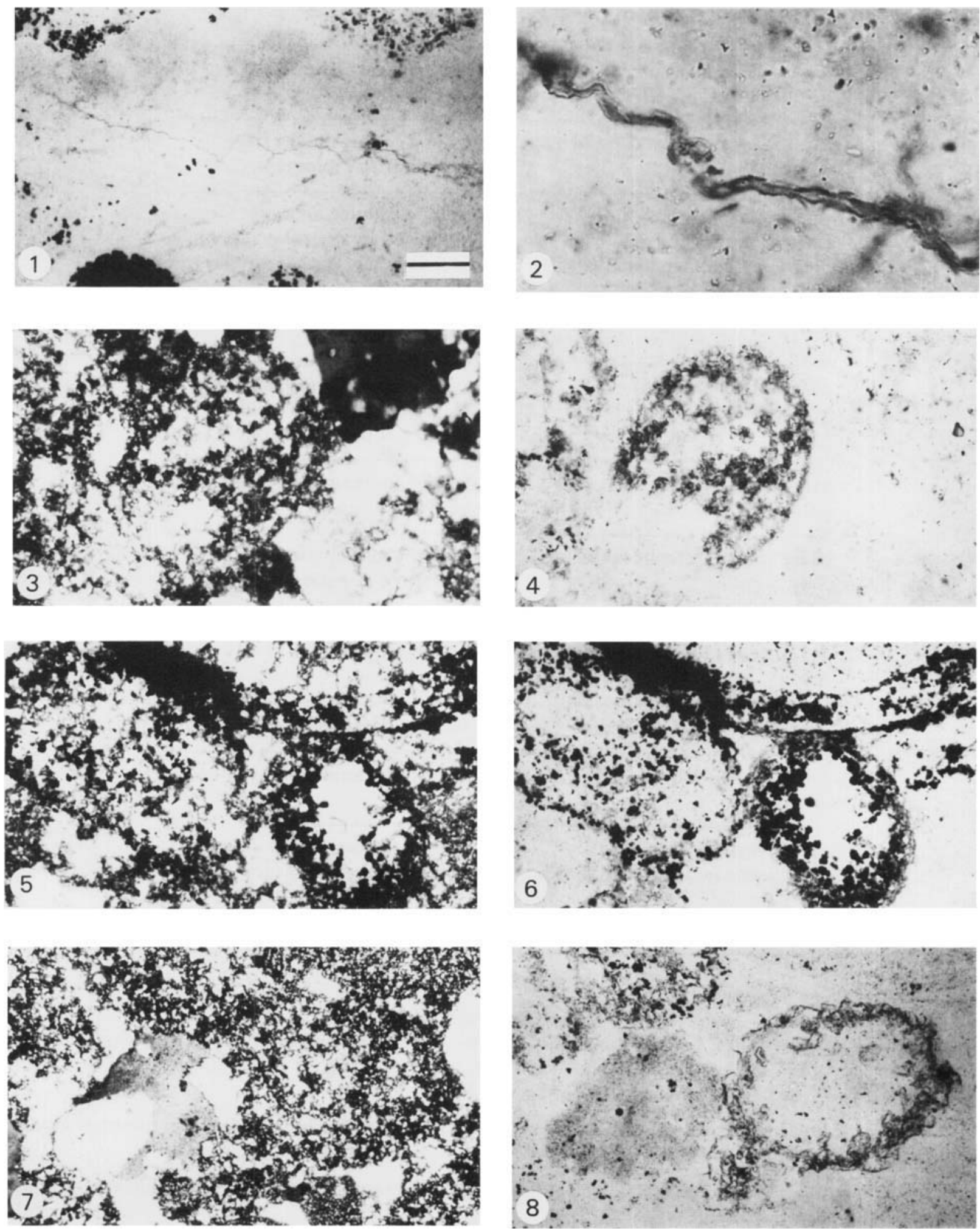
Table 1. Comments on individual microstructures recorded from the pre-Torridonian

\begin{tabular}{|c|c|}
\hline $\begin{array}{l}\text { Original designation } \\
\text { (Muir \& Sutton, 1970) }\end{array}$ & New interpretation \\
\hline carbonaceous rims of ooliths & $\begin{array}{l}\text { brown colour due to finely } \\
\text { granular iron minerals }\end{array}$ \\
\hline $\begin{array}{l}\text { small sphaeroids } \\
\text { chains of cells (fig. } 3 \text { ) } \\
\text { degraded cellular tissue (fig. } 6 \text { ) }\end{array}$ & $\begin{array}{l}\text { abiotic cellular textures } \\
\text { produced by crystal growth in a } \\
\text { matrix rich in finely granular iron }\end{array}$ \\
\hline mucilage-like tissue (fig. 4) & $\begin{array}{l}\text { preparational artefact; } \\
\text { residual iron }\end{array}$ \\
\hline sheet of cells (fig. 5) & $\begin{array}{l}\text { unusually well-preserved } \\
\text { fragment of abiotic cellular } \\
\text { texture or possibly a contaminant }\end{array}$ \\
\hline $\begin{array}{l}\text { irregularly branched chains } \\
\text { of cells }\end{array}$ & $\begin{array}{l}\text { fungal contamination - } \\
\text { conidiospores }\end{array}$ \\
\hline $\begin{array}{l}\text { large masses of cells up to } \\
20 \mu \mathrm{m} \text { across }\end{array}$ & $\begin{array}{l}\text { fungal contamination - } \\
\text { masses of conidiospores }\end{array}$ \\
\hline $\begin{array}{l}\text { Huroniospora microreticulata } \\
\text { Barghoorn in Barghoorn \& Tyler, } \\
1965\end{array}$ & $\begin{array}{l}\text { fungal contamination - } \\
\text { isolated spores }\end{array}$ \\
\hline large non-septate filaments & fungal contamination - hyphae \\
\hline $\begin{array}{l}\text { small, irregularly branching } \\
\text { filaments }\end{array}$ & fungal contamination - mycelia \\
\hline $\begin{array}{l}\text { Entosphaeroides amplus } \\
\text { Barghoorn in Barghoorn \& Tyler, } \\
1965\end{array}$ & $\begin{array}{l}\text { fungal contamination - hyphae } \\
\text { with some cell contents }\end{array}$ \\
\hline
\end{tabular}

\section{Explanation of Plate 2}

Section S19201B1

Scale bar represents $10 \mu \mathrm{m}$ in figs. $1-5,7-9$ and $100 \mu \mathrm{m}$ in fig. 6 . Stage co-ordinates in $\mathrm{mm}$ with S-label to left: fig. 1 , 115.6-14.1; fig. 2, 120.6-15.9; fig. 3, 115.3-13.9; fig. 4, 115.5-15.0; fig. 5, 101.5-15.6; fig. 6, 115.2-06.5; fig. 7, 115.1-06.4; fig. 8, 115.1-06.3; fig. 9, 115.4-06.4. All figs. in PPL.

Fig. 1-5. Abiotic cellular textures resulting from the concentration of finely granular iron minerals along crystal boundaries. Figs. 1 and 3 show part of Pl. 1, fig. 6; fig. 5 shows part of Pl. 1, fig. 8 .

Fig. 6. General view of area of finely crystalline chert showing a crack containing fungal contaminants (a), chalcedony (b) and possible fossil filament (c)

Figs. 7, 8. Needles of chalcedony seen in fig. 6.

Fig. 9. Detail of possible fossil filament seen in fig. 6 . 

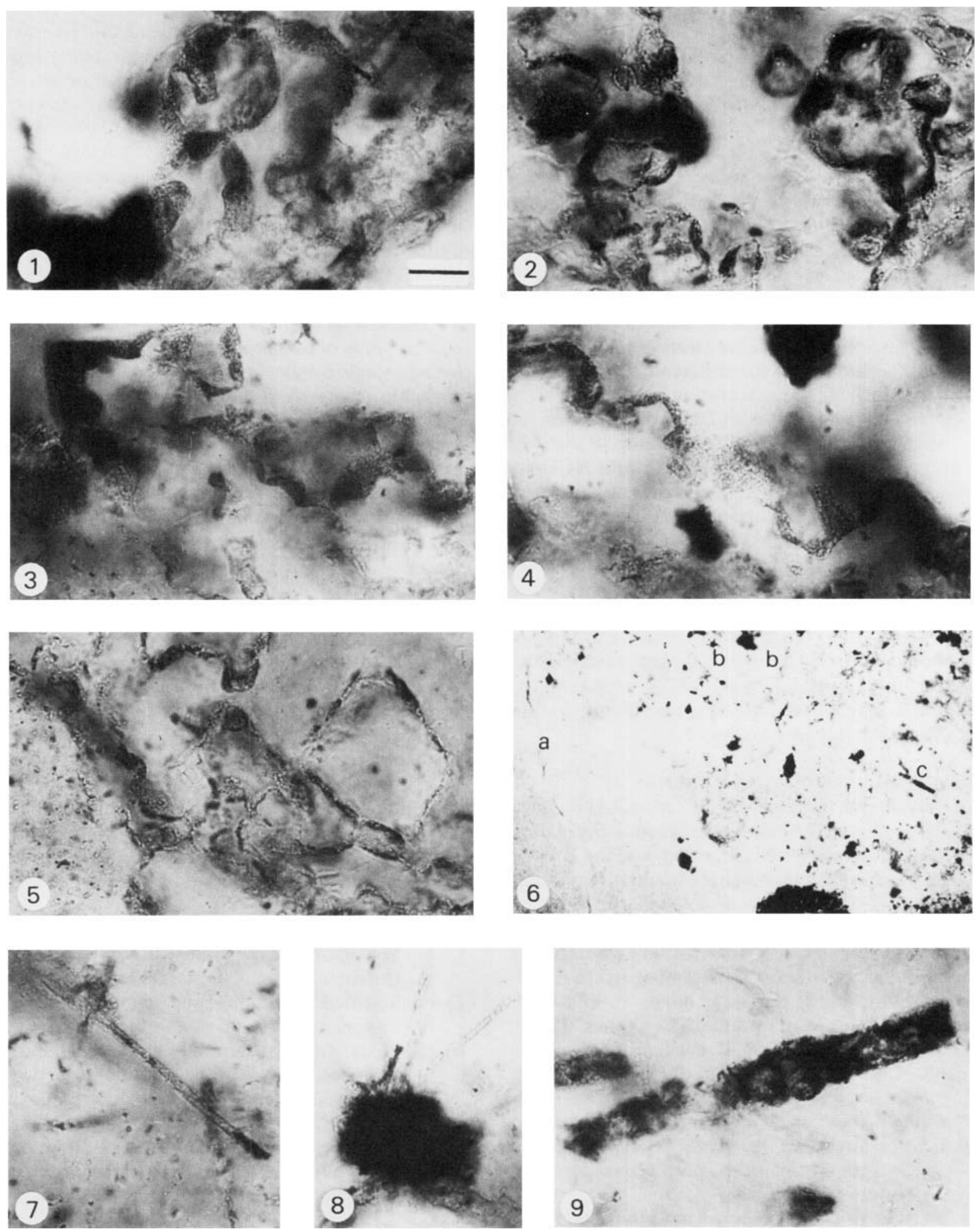
One area of very finely crystalline chert in section S19201B1 does not seem to have been recrystallised (Pl. 2, fig. 6). Here, there are clusters of radiating needles of chalcedony (Pl. 2, figs. $6 \mathrm{~b}, 7,8$ ) and one stubby rough filament (Pl. 2, figs. 6c, 9). This fragment might represent the remains of an iron-encrusted filamentous microorganism, but equally it could have a purely inorganic origin.

I have seen no convincing microfossils in the original thin sections. Since the pebbles were contaminated by fungi, all microstructures recovered from macerations are automatically suspect. Photographs of the macerated residues (unpublished and given to me by Dr. M. D. Muir) show hyphae, mycelial masses and conidiospores. Only one well-preserved sheet of cellular tissue was found, and this may have been a contaminant.

Most iron minerals are dissolved during maceration so at first sight the survival of the abiogenic cellular sheets is surprising. In fact, the maceration regime was very brief, employing treatment with $20 \% \mathrm{HCl}, 40 \% \mathrm{HF}$ for $48 \mathrm{hr}$, then $20 \% \mathrm{HCl}$ followed by washing in distilled water and centrifugation. The treatment with $\mathrm{HCl}$ may not have been long enough to dissolve all the iron minerals. I have found that insoluble fluorides will form unless some $\mathrm{HCl}$ is present throughout maceration, and it is possible that some iron minerals were protected by insoluble layers. Centrifugation can also produce artefacts in the form of lumps and sheets of granular debris. All of the microstructures reported from macerates can be attributed to fungal contamination, the survival of abiotic cellular material, or preparational artefacts. The absence of convincing microfossils in thin sections supports this conclusion.

\section{LONGMYNDIAN AND CHARNIAN}

Assemblages of organic-walled microfossils have recently been reported from the Blackbrook Formation and Maplewell Group of the Charnian, and the Buxton Rock (?) of the Longmyndian (Choubert \& FaureMuret, 1980, p. 190-2; Timofeyev et al., 1980). The microfossils were described only from macerations, and exact sampling sites were not recorded. The assemblages were nondescript, with most species assigned to Protosphaeridium, including the new name $P$. charnium introduced without description. The genus Protosphaeridium Timofeev, 1966 is a superfluous name, being an objective junior synonym of Protoleiosphaeridium Timofeev, 1959 ex Timofeev, 1960. 'Archaeohystricosphaeridium sp.' was recorded from the Charnian and 'Bavlinella faveolata Schep.' from the Longmyndian and, on this basis, both sequences were assigned a Middle Riphean age.

The genus Archaeohystrichosphaeridium Timofeev, 1959 ex Loeblich \& Tappan, 1976 is a junior subjective synonym of Cymatiogalea Deunff, 1961. The taxon included many dissimilar forms and the name is meaning- less (see Loeblich \& Tappan, 1976). The presence of acanthomorph acritarchs would indicate an age younger than uppermost Riphean, and probably much younger.

I am not convinced that Bavlinella faveolata Shepeleva, 1962 can be reliably distinguished from abiogenic framboidal pyrite. In any case, the stratigraphic range of this taxon is longer than suggested, certainly extending up into the Lower Cambrian (Vidal, 1979; this paper gives references to the biogenicity debate).

It is possible that a few sphaeromorphs might be recovered from macerates of Longmyndian samples, but these would hardly be representative because all of the larger forms have been carbonised and fragmented (Peat, 1984). Mr. D. McVey (pers. comm) has examined thin sections of numerous samples from the Charnian over the last six years, and is presently collaborating with me on a study of some core samples. Neither of us has yet found a single convincing fragment of organic debris or a plausible cryptarch in any of this material.

In view of these errors and uncertainties, it would be unwise to accept these reports until the presence of fossils has been confirmed in thin sections of the original samples, and in fresh samples from the same localities. The microfossils will then need to be properly described and identified before any stratigraphic inferences can be drawn.

\section{CONCLUSIONS}

This brief survey of a few British Precambrian microbiotas has demonstrated several serious problems:

a) microfossils have been described from macerations and similar preparations without proper thin section control;

b) microstructures in thin section have been interpreted as fossils on inadequate evidence;

c) contaminating microorganisms have escaped recognition and been described as microfossils;

d) sweeping biostratigraphic statements have been based on dubious fossils and erroneous stratigraphic ranges;

e) sample localities have not been adequately recorded;

f) the geological and mineralogical context of described microstructures has been largely ignored;

g) complicated techniques and high technology have been applied uncritically and without proper controls;

h) the rules of nomenclature have been ignored;

i) preparations and collections have not been deposited in recognised collections and are no longer available for study.

Future studies must avoid these pitfalls if we are ever to achieve an objective account of the Precambrian fossil record.

\section{ACKNOWLEDGMENTS}

It is a privilege to dedicate this paper to Prof. C. Downie who has done so much to encourage studies of 
acritarchs, cryptarchs and Precambrian microbiotas. I thank Mr. W. L. Diver and Mr. P. R. Grant for many discussions at the microscope, and Mr. D. McVey for permission to cite his unpublished work. Dr. M. D. Muir and Prof. J. Sutton encouraged me to study the chert pebbles and I regret that I was unable to confirm their report. Dr. M. D. Muir kindly gave me the negatives of most of her pictures of this material, as well as photographs of the Llanddwyn locality. Dr. A. D. Stewart arranged for me to borrow thin sections of the chert pebbles, and Mr. P. R. Grant lent sections of the Llanddwyn jaspers. Dr. T. D. Ford and Dr. M. J. LeBas kindly permitted sampling of cores from the Charnian. I am also grateful to the Department of Geology \& Mineralogy, Oxford University for the use of their facilities, and Wolfson College, Oxford for a Guy Newton Junior Research Fellowship in Biology.

\section{REFERENCES}

Barber, A. J., Beach, A., Park, R. G., Tarney, J. \& Stewart, A. D. 1978. The Lewisian and Torridonian rocks of NorthWest Scotland. Geologists Ass. Guide No. 21, London.

Barghoorn, E. S. \& Tyler, S. A. 1965. Microorganisms from the Gunflint Chert. Science (Wash.), 147, 563-577.

Choubert, G. \& Faure-Muret, A. 1980. The Precambrian in North peri-Atlantic and South Mediterranean mobile zones: general results. Earth Sci. Revs., 16, 85-219.

Deunff, J. 1961. Un microplancton a hystrichospheres dans le Tremadoc du Sahara. Rev. Micropaléont., 4, (1), 37-52.

Diver, W. L. 1980. Some factors controlling cryptarch distribution in the late Precambrian Torridon Group. 5 Int. Palynol. Conf., Cambridge, 1980, abstracts, p. 113.

Loeblich, A. R. \& Tappan, H. 1976. Some new and revised organic-walled phytoplankton microfossil genera. Jour Paleont., 50, (2), 301-308.

Muir, M. D., Bliss, G. M., Grant, P. R. \& Fisher, M. J. 1979. Palaeontological evidence for the age of some supposedly Precambrian rocks in Anglesey, North Wales. Jour. Geol. Soc. London, 136 (1), 61-64.

Muir, M. D. \& Sutton, J. S. 1970. Some fossiliferous preCambrian chert pebbles within the Torridonian of Britain. Nature 226, (5244), 443-445.
Peat, C. J. 1984. Precambrian microfossils from the Longmyndian of Shropshire. Proc. Geol. Ass., London, 95 (1), 17-22.

Peat, C. J. \& Diver, W. L. 1982. First signs of life on Earth. New. Scientist, 95 (1323), 776-781.

Peat, C. J. \& Lloyd, B. J. 1974. Direct observation of rock macerates. Nature, 251 (5473), 294-295.

Schopf, J. W. \& Walter, M. R. 1983. Archean microfossils: new evidence of ancient microbes. p. 214-239 In Schopf, J. W. (Ed.), Earth's Earliest Biosphere. Its origin and evolution. Princeton Univ. Press, New Jersey. ISBN 0-691-02375-1.

Shepeleva, E. D. 1962. Rastitelnye ? ostatki neizvestnoi sistematicheskoi prinadlezhnosti iz otlozhenii Bavlinskoi Serii Volgo-Uralskoi neftenosnoi provintsii. Dokl. Akad. Nauk. SSSR, 142 (2), 456-457.

Stewart, A. D. 1975. 'Torridonian' rocks of western Scotland. p. 43-51 In Harris, A. L. et al. (Eds.), A correlation of Precambrian rocks in the British Isles, Geol. Soc. London Spec. Report No. 6, Scottish Academic Press, Edinburgh, ISBN 0-7073-0112-2.

Timofeyev, B. V. 1959. Drevneishaya flora pribaltiki i ee stratigraficheskoe znachenie. Trudy vses. neft. nauchnoissled. geol. inst. (VNIGRI), 129, 1-319.

Timofeyev, B. V. 1960. Sur la caracteristique micropalaeontologique de la formation de Visingso. Geol. Foren. Forhandl., 82, (1), 28-42.

Timofeyev, B. V. 1966. Mikropaleofitologicheskoe issledovanie drevnikh svit. Izdat. Nauka Moskva.

Timofeyev, B. V., Choubert, G. \& Faure-Muret, A. 1980. Acritarchs of the Precambrian in mobile zones. Earth Sci. Revs. 16, 249-255.

Vidal, G. 1979. Acritarchs from the upper Proterozoic and lower Cambrian of East Greenland. Gronl. Geol. Unders. Bull. 134.

Williams, G. E. 1966a. The Precambrian Torridonian sediments of the Cape Wrath district, north-west Scotland. PhD Thesis. Reading Univ.

Williams, G. E. 1966b. Palaeogeography of the Torridonian Applecross Group. Nature, 209 1303-1306.

Williams, G. E. 1968. Torridonian weathering, and its bearing on Torridonian palaeoclimate and source. Scott. Jour. Geol. 4 (2), 164-184.

Williams, G. E. 1969a. Characteristics and origin of a Precambrian pediment. Jour. Geol., 77 (2), 183-207.

Williams, G.E. 1969b. Petrography and origin of pebbles from Torridonian strata (late Precambrian), Northwest Scotland. p. 609-629 In North Atlantic - Geology and continental drift. Amer. Ass. Pet. Geol. Memoir 12. 